\title{
Kewenangan tembak di tempat oleh aparat kepolisian terhadap pelaku kejahatan
}

\author{
Shoot authority in place by police apars to criminal applicants
}

\author{
Arief Ryzki Wicaksana \\ Program Studi Magister Kajian Ilmu Kepolisian, Sekolah Pascasarjana Universitas Airlangga \\ Surabaya, 60286, Jawa Timur, Indonesia \\ E-mail: arief.ryzki.wicaksana-2015@pasca.unair.ac.id
}

\begin{abstract}
Abstrak
Dasar hukum tindakan tembak di tempat terhadap pelaku kriminal adalah: Undang-undang Kepolisian Pasal 16 ayat 1 huruf i dan Pasal 16 ayat 2, Pasal 18 ayat 1. Dalam KUHAP diatur dalam Pasal 5 ayat 1 huruf a angka 4; Pasal 7 ayat 1 huruf j; serta dalam Perkap No. 1 Tahun 2009. Batasan tembak di tempat adalah dengan memperhatikan prinsip legalitas, nesesitas, proporsionalitas, kewajiban umum, preventif, masuk akal. Dalam menggunakan diskresinya anggota harus memiliki kemampuan melakukan intepretasi sebagai manifestasi keterampilan, pengamatan, serta pemahaman anggota Polri guna mengambil keputusan diskresi dengan tepat. Analisis data dalam penelitian ini menggunakan analisis kualitatif. Hasil penelitian ini menunjukan bahwa pada dasarnya pemberlakuan tembak ditempat terhadap tersangka merupakan langkah terakhir yang dilakukan oleh anggota Polri. Dari keseluruhan data penembakan pada pelaku kriminalitas di wilayah Polrestabes Surabaya diketahui bahwa penembakan dilakukan petugas sebagai pembelaan terpaksa karena adanya ancaman kehilangan nyawa.
\end{abstract}

Kata Kunci : dasar hukum; diskres; pelaku kriminal; legalitas; kewenangan

\begin{abstract}
The legal basis of in-place firing action against criminals is: Police Law Article 16 paragraph 1 letter I and article 16 paragraph 2, article 18 paragraph 1. In the criminal CODE is governed by article 5 paragraph 1 letter a number 4; Article 7 paragraph $1 \mathrm{~J}$; And in the Perkap No. 1 year 2009. The limit of firing in place is to pay attention to the principle of legality, nesesity, proportionality, general obligations, preventive, reasonable. In using its disagreements, members must have the ability to perform as a manifestation of the skills, observation, and understanding of POLICE members to make appropriate discretionary decisions. Data analysis In this study uses qualitative analysis. The results of this study indicate that the firing effect in place of the suspect is the last step taken by the POLICE members. From the entire data on the shooting of criminal criminality in the territory of Surabaya Polrestabes is known that the shooting was carried out officers as a defence forced due to the threat of loss of life.
\end{abstract}

Keywords: legal basis; discretionary; criminal, legality, authority

\section{Pendahuluan}

Keberhasilan cita-cita Undang-Undang sangatlah ditentukan oleh profesionalisme Polri, yang didukung dengan instrumen hukum yang memberikan ketegasan batas tugasnya (Suyono, 2013). Dilihat tugas Kepolisian Negara Republik Republik Indonesia (Polri) dalam Undang-undang Kepolisian No. 2 Tahun 2002, dapat dikaji antara lain: memelihara kemanan dan ketertiban masyarakat; menegakkan hukum, memberikan perlindungan, pengayoman dan pelayanan kepada masyarakat. Dinamika masyarakat yang terus berubah dengan cepat, diiringi dengan perubahan sosial, budaya dan teknologi, sementara di sisi lain perkembangan tingkat kesejahteraan juga semakin kompleks menuntut tinggi peranan kepolisian untuk mengatasi berbagai pelanggaran hukum yang terjadi (Anwar, 2009).

Jika dilihat dari alasan keberadaannya tugas Polri memiliki tiga aspek, pertama aspek refresif yakni berupa penindakan terhadap mereka yang melakukan pelanggaran hukum, jadi polisi berfungsi sebagai seorang penegak hukum, sedangakan aspek yang kedua adalah tugas preventif yakni meliputi 
tugas perlindungan dan pencegahan terjadinya suatu kejahatan atau pelanggaran, dan aspek pre-emtif yaitu upaya untuk menangkal dan mencegah agar tidak terjadi kejahatan/pelanggaran dengan melakukan deteksi dini maupun pembinaan-pembinaan di lingkungan masyarakat. Untuk melaksanakan tugas ketiganya itu terutama dalam menghadapi tantangan yang lebih serius seperti mengatasi berbagai permasalahan kriminalitas yang semakin hari semakin meresahkan masyarakat dan menjadi gangguan kamtibmas.

Salah satu kewenangan yang dimiliki anggota Polri adalah kewenangan untuk menembak dengan senjata api atau lebih sering kita kenal dengan kewenangan tembak di tempat (Nova, Achmad \& Suzanalisa, 2017). Penggunaan kewenangan ini oleh anggota Polri sering digunakan untuk menangkap pelaku tindak pidana yang melakukan perlawanan, melarikan diri atau diperkirakan akan membahayakan orang lain (Watabisu, 2016). Sebagaimana contoh kejadian tembak di tempat ini terjadi di jalan Tambak Wedi Surabaya. Pelaku AMS alias D yang menjadi target operasi karena kasus pencurian kendaraan bermotor (curanmor), terlihat oleh anggota sedang mengendarai sepeda motor akan memasuki pintu tol mengarah ke Madura, namun melihat petugas tiba-tiba pelaku putar arah dan berusaha melarikan diri, setelah dilakukan pengejaran dan dihentikan di samping pintu gerbang tol, tetapi pelaku tidak mau berhenti dan mengeluarkan celurit lalu berusaha untuk melawan petugas dengan mengayunkan pisau tersebut kearah petugas, karena membahayakan maka petugas mengambil tindakan tegas dengan tembakan peringatan namun tidak diindahkan oleh pelaku tetapi semakin melawan petugas lalu kami tembak arah dada dan langsung setelah tersangka kami larikan ke rumah sakit, tetapi nyawa pelaku tidak terselamatkan. Dari tangan pelaku turut diamankan pula Kunci T serta sebilah celurit untuk aksi kejahatan.

Tindakan tembak ditempat oleh aparat kepolisian merupakan suatu tugas Polisi yang bersifat represif, yaitu bersifat menindak (Knutsson, 2004). Tugas represif Polisi adalah tugas kepolisian yang bersifat menindak terhadap para pelanggar hukum untuk sesuai dengan ketentuan-ketentuan hukum yang berlaku baik didalam KUHAP maupun peraturan perundang-undangan lainnya (Faal, 1991). Kewenangan melakukan tugas represif dalam hal ini tembak ditempat oleh aparat kepolisian disebut dengan diskresi kepolisian aktif, dan umumnya tugas ini kewenangannya diberikan kepada aparat kepolisian unit reserse (Sutanto, Sulistyo \& Sugiarso, 2005). Berdasarkan latar belakang di atas, maka rumusan masalah pada penelitian ini yaitu apa dasar hukum serta batasan dilakukannya tindakan tembak ditempat oleh aparat kepolisian terhadap pelaku kejahatan? Bagaimanakah implementasi serta kendala pelaksanaan kewenangan tembak di tempat oleh aparat kepolisian terhadap pelaku kriminalitas?

\section{Metode Penelitian}

Pendekatan penelitian yang digunakan adalah pendekatan Undang-Undang (statute approach), dan pendekatan konseptual (conceptual approach). Jadi selain melakukan telaah terhadap Undang-Undang terkait permasalahan yang dibahas maka dalam peneliti juga menggunakan pendekatan konseptual, yakni perlunya merujuk pada prinsip-prinsip hukum. Prinsip-prinsip ini dapat diketemukan dalam pandangan-pandangan sarjana melalui teori-teori hukum ataupun doktrin-doktrin hukum (Marzuki, 2009).

Dalam usaha penulis mendapatkan data yang diperlukan untuk penyusunan Tesis, penulis mempergunakan jenis penelitian hukum empiris. Penelitian hukum empiris merupakan salah satu jenis penelitian hukum yang menganalisis dan mengkaji bekerjanya hukum di dalam masyarakat (Salim, 2013; Adiyanta, 2019). Teknik yang digunakan untuk pengumpulan data primer, yaitu dengan wawancara mendalam (depth interview) dengan para informan (Moleong, 1989; Denzin \& Lincoln, 2000; Given, 2008). Salah satu tahap yang paling penting dalam penelitian adalah menganalisis data yang telah diperoleh. Analisis data dalam penelitian ini menggunakan analisis kualitatif (Silalahi, 2009). 


\section{Hasil dan Pembahasan}

\section{Dasar hukum serta batasan dilakukannya tindakan tembak ditempat oleh aparat kepolisian terhadap pelaku kejahatan}

Bila penggunaan senjata api dapat disebut sebagai Kekerasan mematikan "Lethal Weapon" maka upaya lain yang disebut dengan kebijakan penggunaan "kekerasan tidak mematikan" dalam istilah asing disebut sebagai " Non Lethal Weapon". Bentuk kekerasan tidak mematikan (NLW; Non Lethal Weapon) mempunyai lingkup yang luas. Berikut adalah beberapa darinya: Senjata benturan / pemukul; Senjata Kimia; Air bertekanan tinggi; Senjata elektronik; Projektil yang tidak mematikan (peluru karet, kantong biji) sistim paku kendaraan (Cook, McGowan \& Fiely, 1994; Dando, 1996; Veronika, 2013).

Dalam menghadapi pelaku kejahatan yang melakukan tindak kejahatan polisi terkadang harus dilakukan tindakan kekerasan yang menjadi suatu kewenangan tersendiri bagi polisi (Alpert \& Smith, 1994; Bittner, 1975; Skolnick \& Fyfe, 1993; Belur, 2010). Kewenangan melakukan tembak di tempat adalah termasuk kewenangan atribusi. J.G. Brouwer berpendapat bahwa atribusi merupakan kewenangan yang diberikan kepada suatu organ (institusi) pemerintahan atau lembaga Negara oleh suatu badan legislatif yang independen. Kewenangan ini adalah asli, yang tidak diambil dari kewenangan yang ada sebelumnya atau merupakan perintah langsung dari peraturan perundangundangan (Brouwer \& Schilder, 1998).

Adapun mengenai dasar hukum tertulis mengenai pelaksanaan kewenangan tembak di tempat yaitu: (1) Undang-Undang Nomor 2 Tahun 2002 tentang Kepolisian Negara Republik Indonesia Pasal 16 ayat 1 huruf i dan Pasal 16 ayat 2, yang menyatakan "Dalam rangka menyelenggarakan tugas sebagaimana dimaksud dalam Pasal 13 dan 14 di bidang proses pidana, Kepolisian Negara Republik Indonesia berwenang untuk mengadakan tindakan lain menurut hukum yang bertanggung jawab. Tindakan lain sebagaimana dimaksud dalam ayat (1) huruf 1 adalah tindakan penyelidikan dan penyidikan yang dilaksanakan jika memenuhi syarat sebagai berikut: a) tidak bertentangan dengan suatu aturan hukum; b) selaras dengan kewajiban hukum yang mengharuskan tindakan tersebut dilakukan; c) harus patut, masuk akal, dan termasuk dalam lingkungan jabatannya; d) pertimbangan yang layak berdasarkan keadaan yang memaksa; dan e) menghormati Hak Asasi Manusia."

Pasal 18 ayat 1 yang berbunyi "Untuk kepentingan umum pejabat Kepolisian negara Republik Indonesia dalam melaksanakan tugas dan wewenangnya dapat bertindak menurut penilaiannya sendiri". Dimana yang dimaksud dengan "Bertindak menurut penilaiannya sendiri adalah suatu tindakan yang dapat dilakukan oleh anggota kepolisian Negara Republik Indonesia yang dalam bertindak harus mempertimbangkan manfaat serta resikonya dari tindakannya dan betul-betul untuk kepentingan umum. (penjelasan UU Nomor 2 Tahun 2002 Pasal 18 ayat 1) Kitab Undang-Undang Hukum acara Pidana (Undang-Undang Nomor 8 tahun 1981).

Dalam Pasal 5 ayat 1 huruf a angka 4 KUHAP menyatakan bahwa: "Penyelidik sebagaimana dimaksud dalam Pasal 4: karena kewajibannya mempunyai wewenang mengadakan tindakan lain menurut hukum yang bertanggung jawab." Dimana yang dimaksud penyelidik dalam pasal 4 KUHAP adalah setiap pejabat Kepolisian Negara Republik Indonesian. Dan tindakan lain yang dimaksud dalam pasal diatas merupakan tindakan yang masuk dalam diskresi kepolisian.

Diatur dalam Kitab Undang-Undang Hukum Acara Pidana (Undang-Undang Nomor 8 tahun 1981) Pasal 7 ayat 1 huruf j yang berbunyi : "Penyidik sebagaimana dimaksud dalam Pasal 6 ayat (1) huruf a karena kewajibannya mempunyai wewenang : "mengadakan tindakan lain menurut hukum yang bertanggung jawab". Perkap No. 1 Tahun 2009 tentang Penggunaan Kekuatan Dalam Tindakan Kepolisian. Intisari dari Pasal 2 Perkap No. 1 Tahun 2009 berisi mengenai tujuan dari pembentukan Perkap ini yakni untuk memberi pedoman bagi anggota Polri dalam pelaksanaan tindakan kepolisian yang memerlukan penggunaan kekuatan, sehingga terhindar dari penggunaan kekuatan yang berlebihan atau tidak dapat dipertanggungjawabkan. 
Tahapan penggunaan senjata api diatur dalam peraturan Kapolri No 1 Tahun 2009 tentang penggunaan kekuatan dalam tindakan kepolisian, pasal 5 ayat 1 menyebutkan enam tahapan penggunaan kekuatan dalam tindakan kepolisian yang terdiri dari: a) Tahap 1: kekuatan yang memiliki dampak pencegahan. Dalam prakteknya, saat polisi berdiri menggunakan seragam, dia sudah menggunakan kekuatan tahap 1; b) Tahap 2: perintah lisan. Kalau misalnya keberadaan polisi saja tidak membuat pelaku takut, maka polisi akan berteriak atau menyebutkan nama bahwa dia anggota polisi. Saat polisi mengeluarkan suara, maka itulah tahap 2; c) Tahap 3: kendali tangan kosong lunak. Misalnya orang tersebut tidak mau berhenti, dan terus mendekati petugas, petugas akan mencoba menahan dengan tangan. Saat tangan petugas bersentuhan dengan tubuh tersangka, maka itulah tahap 3; d) Tahap 4: kendali tangan kosong keras. Tersangka ini tetap melawan, membuat petugas menggunakan gerakan bela diri untuk menghentikan tersangka. Ini lah tahap ke 4; e) Tahap 5: kendali senjata tumpul, senjata kimia antara lain gas air mata, semprotan cabe atau alat lain sesuai dengan standar Polri. Jika sudah dilakukan perlawanan tetapi tetap saja melawan, maka petugas dapat menggunakan senjata tumpul atau senjata kimia. Misalnya tongkat T, double stick, tongkat rotan, tameng dalmas atau gas air mata; f) Tahap 6: kendali dengan menggunakan senjata api atau alat lain yang menghentikan tindakan atau perilaku kejahatan atau tersangka yang dapat menyebabkan luka parah atau kematian anggota Polri atau anggota masyarakat. Tahap akhir ini lah seorang petugas menggunakan senjata api.

Batasan situasi dan kondisi dapat diberlakukannya perintah tembak di tempat yaitu harus sesuai dengan ketentuan yang terdapat dalam penggunaan senjata api oleh Polri, terutama ketentuan tentang penggunaan senjata api oleh Polri berdasarkan SOP di dalam Buku Pedoman Pelaksanaan Tugas bintara Polri Di Lapangan Tahun 2004 adalah: a) hanya digunakan dalam keadaan terpaksa; b) untuk membela diri sendiri atau orang lain dan ancaman mati atau luka parah dalam jarak dekat; c) untuk mencegah kejahatan yang sangat yang menimbulkan ancaman terhadap nyawa; d) untuk menangkap atau mencegah larinya orang yang telah melakukan ancaman dan menolak untuk menghentikan ancaman-ancaman; e) penggunaan senjata api yang mematikan secara sengaja diperkenankan apabila sama sekali tidak dapat dihindari untuk melindungi kehidupan manusia; f) dilakukan karena terpaksa untuk membela diri atau orang lain karena ada ancaman serangan yang melawan hukum terhadap kehormatan, harta benda sendiri maupun orang lain; g) dilakukan tetap dalam kendali dan diarahkan untuk tujuan menyerah secepatnya; h) dilakukan tidak berlebihan, hindari kerugian baik fisik dan material; i) dilakukan tidak untuk menciptakan penderitaan dan memberikan jaminan kepada mereka yang menyerah, luka, dan sakit; j) tidak menyakiti yang tidak berdaya dan tidak menjurus perbuatan yang biadab/brutal.

Untuk mengatasi permasalahan kecerdasan emosional bagi anggota Polri yang menguasai senjata api, diatur pemeriksaan serta penilaian yang ketat agar tidak terjadi penyalahgunaan wewenang. Pemeriksaan dan penilaian itu dipaparkan dalam Perkap Nomor 4 Tahun 2007 mengenai Tata Cara Pemeriksaan Psikologi Bagi Calon Pemegang Senjata Api Organik Kepolisian Negara Republik Indonesia Dan Non-Organik Tentara Nasional Indonesia/ Kepolisian Negara Republik Indonesia. Pemeriksaan psikologi bagi anggota Polri memiliki aspek psikologi dan instrumen yang disebutkan dalam Pasal 3 Perkap No. 4 Tahun 2007 yang menyatakan bahwa aspek psikologi yang diungkap dalam pemeriksaan psikologi bagi calon pemegang senjata api organik Polri dan non-organik TNI/ Polri meliputi aspek pencetus; dan aspek penghambat. Aspek psikologi pencetus tersebut antara lain: a) impulsif atau tidak mampu menahan dorongan untuk bertindak; b) mudah tersinggung; c) agresif atau dorongan menyakiti orang lain; d) dorongan melukai diri sendiri; e) pamer; f) mempunyai prasangka yang tinggi terhadap orang lain; g) lalai atau kecenderungan berperilaku memperbolehkan barang-barangnya yang khusus dipinjam orang lain dan meletakkan barang-barang di sembarang tempat; dan h) mempunyai masalah yang serius dalam rumah tangga.

Aspek psikologi penghambat adalah penyesuaian diri yang baik; pengendalian diri; super ego yang kuat atau menghargai nilai-nilai/aturan-aturan yang berlaku; dorongan humanisme yang tinggi; alternatif pemecahan masalah atau mampu memilih alternatif yang tepat dalam menyelesaikan permasalahan'; dan daya tahan terhadap stres. Dalam Pasal 6 Perkap No. 4 Tahun 2007, pemeriksaan psikologi menggunakan metode antara lain psikotes; wawancara; observasi; dan dokumentasi. Dari tes tersebut akan dihasilkan evaluasi yang dilakukan untuk menilai aspek-aspek pencetus dan penghambat 
yang mempengaruhi perilaku pemegang senjata api. Evaluasi terhadap aspek-aspek pencetus dan penghambat adalah menilai ada tidaknya aspek pencetus dan kuat tidaknya aspek penghambat. Sehingga berdasar Pasal 8 Perkap No. 4 Tahun 2007, hasil evaluasi tersebut akan menyimpulkan bahwa calon pemegang senjata api tersebut memenuhi syarat atau tidak. Anggota Polri calon pemegang senjata api dianggap memenuhi syarat jika aspek penghambat mendapat nilai minimal "Cukup" dan aspek pencetus tidak ada. Dianggap "Tidak Memenuhi Syarat" jika aspek penghambat ada yang mendapat nilai "Kurang" atau ada aspek pencetus. (Pasal 8 ayat 2 dan 3 Perkap No. 4 Tahun 2007). Untuk Surat Keterangan Hasil Pemeriksaan Psikologi akan dituangkan dalam bentuk psikogram sebagai dasar pembuatan Surat Keterangan Hasil Pemeriksaan Psikologi. Surat Keterangan Hasil Pemeriksaan Psikologi diterbitkan sebagai tanda bahwa yang bersangkutan sudah mengikuti tes psikologi dan dikategorikan Memenuhi atau Tidak Memenuhi Syarat sebagai pemohon/calon pemegang senjata api organik Polri dan non organik TNI/ Polri. Surat Keterangan Hasil Pemeriksaan Psikologi diberikan 3 (tiga) hari setelah pelaksanaan pemeriksaan psikologi untuk pemeriksaan yang dilakukan secara individual dan 10 (sepuluh) hari setelah pelaksanaan pemeriksaan psikologi untuk pemeriksaan yang dilaksanakan secara klasikal. Surat Keterangan Hasil Pemeriksaan Psikologi tersebut berlaku untuk jangka waktu 1 (satu) tahun terhitung sejak tanggal dikeluarkannya Surat Keterangan Hasil Pemeriksaan Psikologi dimaksud.

\section{Implementasi kewenangan tembak di tempat oleh aparat kepolisian terhadap pelaku kriminalitas serta kendala dalam pelaksanaannya}

Adapun berdasarkan analisis penulis, maka motivasi yang ada pada diri anggota di lapangan untuk tidak ragu-ragu bertindak tegas sesuai SOP dengan melakukan tindakan tembak di tempat adalah: a) motivasi untuk melindungi keselamatan nyawa diri sendiri dan orang lain. Kewajiban anggota Polri untuk melindungi nyawa, baik diri sendiri maupun orang lain adalah sesuai dengan apa yang diamanahkan sesuai dengan Pasal 14 Undang-Undang Nomor 2 tahun 2002 tentang Kepolisian Negara Republik Indonesia, yang menyetbutkan bahwa dalam melaksanakan tugas pokok Kepolisian Negara Republik Indonesia bertugas untuk melindungi keselamatan jiwa raga dengan menjunjung tinggi hak asasi manusia.

Pasal 3 Peraturan Kepala Kepolisian Negara Republik Indonesia Nomor 1 Tahun 2009 juga mengatur bahwa prinsip-prinsip penggunaan kekuatan sebagai batas dalam tindakan kepolisian (diskresi) anggota Polri diberi kewenangan untuk bertindak atau tidak bertindak menurut penilaian sendiri, untuk menjaga, memelihara ketertiban dan menjamin keselamatan umum. Lebih jelas lagi dalam Pasal 47 Perkap No. 8 Tahun 2009 yang menyatakan bahwa penggunaan senjata api hanya boleh digunakan bila benar-benar diperuntukkan untuk melindungi nyawa manusia; b) motivasi dari Pimpinan Dalam Memberikan Arahan Cara Menggunakan Diskresi Anggota di Lapangan.

Disebutkan pula dalam Pasal 14 ayat 2 Perkap No. 1 Tahun 2009 bahwa setiap anggota yang menggunakan kekuatan dalam tindakan kepolisian wajib memperhatikan arahan pimpinan dan menjadikannya sebagai pertimbangan dalam menerapkan diskresi kepolisian.Hal tesebut dinyatakan pula dalam wawancara dengan anggota Satreskrim Polrestabes Surabaya sebagai berikut: a) pimpinan selalu menyampaikan berkali-kali mengenai kepercayaannya pada anggota dilapangan bahwa ia bisa menggunakan kewenangannya secara proporsional sesuai SOP; b) perintah pimpinan selalu menekankan tindakan tegas tetapi sesuai dengan prosedur atau SOP; c) arahan pimpinan bahwa kalau pelaku kriminalitas membahayakan nyawa khususnya petugas, maka tembak di tempat harus dilakukan tanpa kekhawatiran. Pengaruh gaya kepemimpinan berupa pengarahan yang baik, pembinaan mental anggota serta motivasi kinerja harian terhadap anggota mengakibatkan semakin tinggi kinerja jajaran yang dihasilkan (Sakti, 2016).

\section{Dukungan positif masyarakat terhadap tindakan tegas Polri dalam melakukan penembakan terhadap pelaku kejahatan yang meresahkan}

Dari sisi dukungan publik terhadap perintah tembak di tempat ini, masyarakat pada umumnya mendukung kebijakan ini. Hal tersebut sebagaimana dalam wawancara pengemudi ojek online 
berisinial A yang berusia 37 Tahun yang sepenuhnya mendukung apa yang dilakukan oleh polisi. Menurutnya, tindakan tegas kepada pelaku kriminalitas terutam jambret atau begal bisa memberi efek jera sehingga tidak melahirkan penjahat- penjahat baru.

Faktor dukungan masyarakat yang dalam hal ini termasuk opini publik, menurut Soerjono Soekanto sangat vial dalam penegakan hukum (Soekanto, 1986; Maxson, Hennigan \& Sloane, 2003; Miller, 2009). Menurut Wiliam Albiq, opini publik adalah jumlah dari pendapat individu- individu yang diperoleh melalui perdebatan dan opini publik merupakan hasil interaksi antar individu dalam suatu publik (Sastropoetro, 1990). Sedangkan opini publik adalah sekumpulan pandangan individu terhadap isu yang sama, yang berhubungan dengan arah opini, pengukuran intensitas, stabilitas, dukungan informasi, dan dukungan sosial (Olii, 2011).

Tidak dipungkiri bahwa terkadang aksi tembak di tempat mendapat hambatan-hambatan pelaksanaan di lapangan. Dari data Pelaku yang ditembak mati, diketahui bahwa pelaku ditembak karena melawan petugas dan beberapa petugas menjadi korbannya bahkan cedera serius. Apa yang dilakukan petugas, menurut analisa penulis adalah suatu "Pembelaan Terpaksa. Mengenai hal ini secara tegas diatur dalam Kitab UndangUndang Hukum Pidana (KUHP) Pasal 49 ayat (1) tentang Noodweer dan ayat (2) tentang 'Noodweer Exces'. Pasal 49 ayat (1) KUHP mengatur tentang Pembelaan Terpaksa (Noodweer), yang rumusannya 'Barang siapa terpaksa melakukan perbuatan untuk pembelaan, karena ada serangan atau ancaman serangan ketika itu yang melawan hukum, terhadap diri sendiri maupun orang lain, terhadap kehormatan kesusilaan, atau harta benda sendiri maupun orang lain, tidak dipidana'. Pembelaan terpaksa, berkaitan dengan prinsip pembelaan diri.

Dalam pembelaan terpaksa ada perbuatan yang melanggar kepentingan hukum orang lain, namun perbuatan tersebut dibenarkan oleh hukum karena memenuhi syarat-syarat yang ditentukan undangundang, yakni : perbuatan tersebut dilakukan karena ada serangan atau ancaman serangan yang bersifat seketika,serangan atau ancaman serangan tersebut bersifat melawan hukum serangan tersebut ditujukan terhadap diri sendiri atau orang lain, kehormatan kesusilaan, dan harta benda baik milik sendiri maupun orang lain, pembelaan tersebut harus dilakukan dengan memperhatikan asas subsidiaritas dan proporsionalitas harus dipenuhi. Pertimbangan karena melaksanakan ketentuan undang- undang, melaksanakan ketentuan yang dimaksud adalah undang- undang dalam arti materil, yaitu setiap peraturan yang dibentuk oleh pembentuk undang-undang yang berlaku dan mengikat umum. Orang yang melakukan perbuatan yang jika memang tindakan diskresi tersebut "dianggap" melanggar hukum dalam rangka melaksanakan undang-undang, maka tindakan tersebut dapat dibenarkan dan tidak melanggar HAM.

Dari penelitian Kompolnas pula menyebutkan bahwa mengenai proses pembelajaran pengetahuan diskresi di jajaran Polri terkait pemberian ajaran pengetahuan diskresi di lembaga pendidikan Polri belum mendapatkan perhatian yang serius dan belum dilaksanakan secara koseptual dengan kondisi sebagai berikut: a) umumnya pembelajaran diberikan bukan melalui mata pelajaran khusus tentang diskresi, melainkan diselipkan dalam mata pelajaran tentang fungsi teknis kepolisian, atau pelajaran lain yang terkait dengan diskresi; b) terkecuali di Akpol mata pelajaran khusus tentang Diskresi telah mulai diajarkan sejak sudah 1 dasawarsa dengan durasi pelajarannya selama satu semester.

Agar diskresi dapat diterapkan secara tepat maka tentunya diperlukan pengetahuan dan pemahaman yang mendalam dari setiap Anggota Polri mengenai ketentuan batasan penerapan diskresi dan, bahkan mengenai sumber- sumber hukum ten tang diskresi serta dasar filosofinya. Hal ini sangat diperlukan agar tindakan yang dilakukan oleh petugas Polri tidak sampai salah atau dapat dipersalahkan. Mengingat tindakan diskresi merupakan instant decision (tanpa rencana) dan harus dilakukan segera oleh petugas dalam menghadapi masalah di lapangan, dibutuhkan pemahaman dan kemahiran petugas agar tindakan diskresi yang dilakukan tidak menyimpang atau dapat dipersalahkan.

Lemahnya bekal dan pedoman menjadi tidak tepat atau bahkan sering terjadi penyimpangan baik yang disengaja ataupun yang tidak disadari oleh petugas. Pemahaman yang terbatas dan persepsi di kalangan petugas mengenai konsep diskresi yang masih berbeda-beda, tentunya akan semakin 
menyulitkan standar penerapan diskresi dan pengawasannya, sehingga hal tersebut juga berpengaruh terhadap kualitas penerapan diskresi. Tingkat keramaian publik yang dimaksud disini adalah dalam hal suatu tindak pidana yang terjadi pada suatu tempat yang terdapat banyak orang berkumpul dan memiliki tingkat keramaian yang tinggi maka hal ini juga merupakan kendala bagi petugas kepolisian dalam melakukan tindakan tembak di tempat terhadap pelaku kejahatan yang membahayakan jiwa orang baik masyarakat maupun petugas kepolisian yang bersangkutan.

Jarak tembak yang jauh pun menjadi suatu kendala tersendiri bagi petugas kepolisian yang hendak melakukan tindakan tembak di tempat terhadap pelaku tindak pidana. Jarak tembak yang cukup jauh pada saat melakukan pengejaran terhadap pelaku tindak pidana yang melarikan diri adalah kendala tersendiri. Selain itu Kondisi cuaca juga merupakan kendala yang dihadapi petugas kepolisian dalam melakukan wewenang tembak di tempat terhadap pelaku tindak pidana, karena apabila cuaca buruk seperti gerimis, hujan, berkabut, angin penerapan diskresi dapat mengakibatkan petugas dalam menerapkan diskresi kencang dan cuaca ekstrem lainnya juga dapat menjadi suatu kendala bagi pihak kepolisian karena apabila polisi tetap memaksakan melakukan tindakan tegas berupa menggunakan kekuatan senjata api, maka hal tersebut juga dapat membahayakan orang lain yang bukan dan atau tidak terlibat sama sekali dengan tindak pidana yang bersangkutan. Sehingga apabila cuaca buruk dan tidak memungkinkan untuk melakukan tindakan tembak di tempat sebisa mungkin petugas kepolisian hanya melakukan pengejaran terhadap pelaku kejahatan dan hanya melakuakan tahapan penggunaan kekuatan yang memiliki dampak deterrent/pencegahan.

Sehingga berdasarkan hal tersebut maka dibutuhkan skill yang mumpuni dari petugas dalam melakukan penembakan. Upaya pelatihan menembak secara rutin adalah kuncinya. Latihan ini bertujuan untuk mengasah kemampuan (skill) setiap petugas kepolisian yang mempunyai ijin menggunakan senjata api agar kemampuan dalam hal menembak dapat semakin meningkat dan semakin akurat. Pelatihan menembak oleh Polrestabes Surabaya dilakukan secara rutin dalam jangka waktu 6 (enam) bulan sekali. Pelatihan ini diutamakan untuk memberikan pemahaman bagi petugas kepolisian yang berhak memegang senjata api agar apabila terjadi tindak pidana secara nyata maka setiap petugas kepolisian harus mengarahkan tembakan pada bagian tubuh pelaku kejahatan yang memiliki risiko paling kecil terhadap kematian agar pelaku tersebut dapat diproses hukum lebih lanjut. Apabila polisi sangat perlu untuk menerapkan tindakan keras berupa penggunaan senjata api maka tembakan yang dilepaskan diutamakan harus ditujukan pada bagian kaki dan tangan karena sifatnya hanya mencegah terjadinya kejahatan berat atau yang mengancam jiwa orang dan untuk menahan, mencegah atau menghentikan seseorang yang sedang atau akan melakukan tindakan yang sangat membahayakan jiwa.

\section{Simpulan}

Dasar hukum tindakan tembak di tempat terhadap pelaku kriminal adalah: Undang-undang Kepolisian Pasal 16 ayat 1 huruf i dan Pasal 16 ayat 2, Pasal 18 ayat 1. Dalam KUHAP diatur dalam Pasal 5 ayat 1 huruf a angka 4; Pasal 7 ayat 1 huruf j; serta dalam Perkap No. 1 Tahun 2009. Batasan tembak di tempat adalah dengan memperhatikan prinsip legalitas, nesesitas, proporsionalitas, kewajiban umum, preventif, masuk akal. Dalam menggunakan diskresinya anggota harus memiliki kemampuan melakukan intepretasi sebagai manifestasi keterampilan, pengamatan, serta pemahaman anggota Polri guna mengambil keputusan diskresi dengan tepat. Pada dasarnya pemberlakuan tembak ditempat terhadap tersangka merupakan langkah terakhir yang dilakukan oleh anggota Polri. Dari keseluruhan data penembakan pada pelaku kriminalitas di wilayah Polrestabes Surabaya diketahui bahwa penembakan dilakukan petugas sebagai pembelaan terpaksa karena adanya ancaman kehilangan nyawa.

Motivasi anggota Polri untuk bertindak tegas dan terukur dalam tembak di tempat pelaku kriminal adalah motivasi untuk melindungi keselamatan nyawa diri sendiri dan orang lain, motivasi pimpinan dalam memberikan arahan cara menggunakan diskresi anggota di lapangan, dukungan positif masyarakat terhadap tindakan tegas Polri dalam melakukan penembakan terhadap pelaku kejahatan yang meresahkan. Hambatan dalam melaksanakan diskresi ini yakni adanya pendapat bahwa tembak di 
tempat melanggar asas praduga tak bersalah, kurangnya pemahaman mengenai cara menggunakan disresi, serta kendala pada kerumunan masa serta jarak tembak petugas dengan pelaku.

\section{Daftar Pustaka}

Adiyanta FS (2019) Hukum dan studi penelitian empiris: Penggunaan metode survey sebagai instrumen penelitian hukum empiris. Administrative Law \& Governance Journal 2 (4):697709. https://doi.org/10.14710/alj.v2i4.697 - 709

Alpert G \& Smith WC (1994). How reasonable is the reasonable man?: Police and excessive force. The Journal of Criminal Law \& Criminology 85 (2). Northwestern University. USA.

Anwar Y (2009) Sistem Peradilan Pidana. Bandung: Widya Padjadjaran.

Belur J (2010) Permission to Shoot? Police Use of Deadly Force in Democracies. USA: Springer Science \& Business Media.

Bittner E (1975) The Functions of the Police in Modern Society. New York: Jason Aronson.

Brouwer JG \& Schilder AE (1998) A Survey of Dutch Administrative Law. Nijmegen: Ars Aequi Libri.

Buku Pedoman Pelaksanaan Tugas bintara Polri di Lapangan (2004).

Cook JW, McGowan, MT, \& Fiely, DP (1994) Non-lethal weapons technologies, legalities, and potential policies. United States Air Force Academy Journal of Legal Studies 5 (2).

Dando M (1996) A New Form of Warfare: The rise of non-lethal weapons. Brassey's Ltd. ISBN: 9781857531275 .

Denzin NK, Lincoln, YS (2000) The Sage Handbook of Qualitative Research. Third Edition. Sage.

Faal M (1991) Penyaringan Perkara Pidana Oleh Polisi (Diskresi Kepolisian), Jakarta: Pradnya Paramita.

Given LM (Ed.) (2008) The Sage Encyclopedia of Qualitative Research Methods. USA: Sage Publications.

Knutsson J (2004) Police Use of Firearms a Constant? The Swedish and Norwegian Experience. Policing in Central and Eastern Europe: Dilemmas of Contemporary Criminal Justice.

Marzuki PM (2009) Penelitian Hukum. Jakarta: Kencana.

Maxson CL, Hennigan K \& Sloane DC (2003) Factors that Influence Public Opinion of the Police. Washington, DC: US Department of Justice, Office of Justice Programs, National Institute of Justice.

Miller JM (Ed.) (2009) 21st Century criminology: A reference handbook (Vol. 1). USA: Sage Publications.

Moleong LJ (1989) Metodologi Penelitian Kualitatif. Bandung: Rosda Karya.

Nova RA, Achmad R \& Suzanalisa S (2017) Pertanggungjawaban dalam pelaksanaan kewenangan tembak di tempat yang dimiliki oleh anggota Polri. Legalitas: Jurnal Hukum 7 (1):145-209.

Sakti FAG (2016) Pengaruh Gaya Kepemimpinan, Disiplin Kerja dan Lingkungan Kerja Terhadap Kinerja Jajaran Polres Boyolali. Tesis: Fakultas Ekonomi dan Bisnis Universitas Muhammadiyah Surakarta.

Salim HS (2013) Penerapan Teori Hukum Pada Tesis dan Disertasi. Jakarta: Rajagrafindo Persada.

Sastropoetro S (1990) Pendapat Publik, Pendapat Umum dan Pendapat Khalayak. dalam Komunikasi Sosial. Bandung: Remaja Rosdakarya.

Silalahi U (2009) Metode Penelitian Sosial. Bandung: Refika Aditama.

Skolnick JH \& Ffye JJ (1993) Above the Law: Police and the Excessive Use of Force. New York: The Free Press.

Soekanto S (1986) Faktor-Faktor yang Mempengaruhi Penegakan Hukum. Jakarta: CV. Rajawali.

Sutanto, Sulistyo H \& Sugiarso T (2005) Manajemen Investigasi. Cet. Pertama. Jakarta: Pensil-324.

Suyono YU (2013) Hukum Kepolisian: Kedudukan Polri dalam Sistem Ketatanegaraan Indonesia Setelah Perubahan UUD 1945. Jakarta: Laksbang Grafika.

Veronika B (2013) Studi kasus mengenai tembak di tempat tersangka: Beberapa tugas dan wewenang Polri. Lex et Societatis 1 (3). 